\title{
Association between vitamin D receptor polymorphisms and haplotypes with pulmonary tuberculosis
}

\author{
SAEEDEH SALIMI ${ }^{1,2}$, FARZANEH FARAJIAN-MASHHADI ${ }^{1,3}$, ROYA ALAVI-NAINI ${ }^{4,5}$, \\ GOLBARG TALEBIAN $^{4}$ and MEHRNAZ NAROOIE-NEJAD ${ }^{6,7}$
}

\author{
${ }^{1}$ Cellular and Molecular Research Center; Departments of ${ }^{2}$ Clinical Biochemistry and ${ }^{3}$ Pharmacology, School of Medicine; \\ ${ }^{4}$ Infectious Diseases and Tropical Medicine Research Center; ${ }^{5}$ School of Medicine; ${ }^{6}$ Department of Genetics, \\ School of Medicine; ${ }^{7}$ Genetic of Non-Communicable Disease Research Center, \\ Zahedan University of Medical Sciences, Zahedan 9816743175, Iran
}

Received October 24, 2014; Accepted November 11, 2014

DOI: $10.3892 /$ br. 2014.402

\begin{abstract}
The vitamin D receptor (VDR) is an important factor in activating immune response in different infectious diseases. The aim of the present study was to investigate the association between the VDR gene polymorphisms and pulmonary tuberculosis (PTB). The case control study was performed on 120 PTB patients and 131 healthy controls. Genetic analysis was performed by polymerase chain reaction and the restriction fragment length polymorphism method. The VDR Fokl Ff genotype was associated with TB and the risk of PTB was two times higher in individuals with the $F f$ genotype. A higher frequency of $f$ allele was observed in PTB patients and therefore, the $f$ allele may be a risk factor for PTB susceptibility. There were no associations between the Taql and Bsml polymorphisms and PTB. In addition, haplotype analysis showed that the $f-T-B$ and $f-t-b$ haplotypes (Fokl, Taql and Bsml) may have the potential to increase PTB susceptibility. In conclusion, the $F f$ genotype and $f$ allele of the VDR Fokl polymorphism were associated with PTB susceptibility. In addition, the $f-T-B$ and $f-t-b$ haplotypes may be the susceptible haplotypes for PTB.
\end{abstract}

\section{Introduction}

Tuberculosis (TB) is the result of infection with Mycobacterium tuberculosis (M. tuberculosis) and is a significant cause of morbidity and mortality worldwide. Each year $>9$ million people are infected by $\mathrm{TB}$ and $>1.7$ million succumb to TB annually (1). The incidence of TB in Iran has been reported

Correspondence to: Dr Farzaneh Farajian-Mashhadi, Cellular and Molecular Research Center, and Department of Pharmacology, School of Medicine, Zahedan University of Medical Sciences, Khalije Fars High Way, Zahedan 9816743175, Iran

E-mail: dr_farajian@yahoo.com

Key words: vitamin D receptor, pulmonary tuberculosis, gene, polymorphism, haplotype as 13.7 per 100,000 in 2009; however, its incidence was higher in the Sistan-Balouchestan province, southeastern Iran. The higher incidence is due to bordering with Afghanistan and Pakistan; two countries with a high TB prevalence (2). Cell-mediated immunity is essential for suppression of Mycobacterial infection as it is an intracellular parasite (3). The fact that only $10 \%$ of those infected with M. tuberculosis progress to clinical disease revealed that genetic factors, as well as environmental factors are involved in the pathophysiology of TB (4).

In addition, the host genetic basis of TB has been confirmed by twin studies that indicated a two times higher risk of disease in identical twins compared to non-identical twins (5).

Several genes have been found to play a role in TB susceptibility and the relative significance of these genes in disease progression or various forms of disease is often modified by the ethnicity in different populations (6).

The active form of vitamin D, 1-25-dihydroxyvitamin $\mathrm{D}_{3}$, is an important hormone that modulates the activity of different defense and immune cells, including lymphocytes, monocytes, macrophages and epithelial cells (7). Since vitamin $\mathrm{D}_{3}$ increases phagocytosis via the activation of macrophages and affects immune response, it is potentially involved in the development of several diseases (8). Vitamin $\mathrm{D}_{3}$ may limit the growth of M. tuberculosis in macrophages (7). Vitamin $\mathrm{D}_{3}$ exerts its effects through the vitamin $\mathrm{D}$ receptor (VDR) and regulates numerous target genes by binding to its nuclear receptor. Active VDR binds to vitamin D response elements that are located in the promoter region of target genes and controls the transcription of these genes (9). The $V D R$ gene is located in chromosome 12 cen-q12, including at least five promoter regions, eight exons that code proteins and six untranslated exons, which are alternatively spliced. Since there are several polymorphisms in the $V D R$ gene that may affect VDR activity, those polymorphisms have been known as potential candidates for genetic susceptibility to TB $(10,11)$.

The Fokl polymorphism (rs2228570) of the VDR gene, which is located in the translation initiation start site, produces two versions of the VDR protein with different lengths (three amino acids). The short protein, which is encoded by the ' $F$ ' allele, is more active than the longer one. Additionally, 
other studies have presented several polymorphisms in strong linkage disequilibrium (LD) in the $3^{\prime}$ untranslated region (3'UTR) of the VDR gene, including Taql (rs731236), Bsml (rs154410) and Apal (rs7975232). Polymorphisms can be detected by restriction fragment length polymorphism (RFLP). This region of the VDR gene regulates gene expression. Therefore, the polymorphisms that are located in this region may influence VDR activity (12). Thus, the present study was designed to evaluate the possible role of the $V D R$ Fokl, Taql and Bsml polymorphisms and haplotypes on pulmonary TB (PTB) susceptibility in a local population of southeastern Iran.

\section{Materials and methods}

Patient selection. The case-control study was conducted prospectively at a university-affiliated hospital (Boo-Ali Hospital, Zahedan, southeastern Iran). The hospital is a referral center for TB. The study was conducted between March 2010 and May 2011 and a total of 120 patients were selected. Diagnosis of pulmonary TB was made by clinical findings; positive sputum smear for acid-fast bacilli and the results of chest X-ray, but only patients who were confirmed by culture were included in the study. Patients affected with other diseases or conditions, such as myocardial infarction, cirrhosis, acute pancreatitis and septic shock, were excluded from the study. A total of 131 normal healthy subjects who underwent the physical examination at Boo-Ali Hospital were recruited during the study period and were matched for age, gender, ethnicity and geographical origin to patients. The inclusion criteria for normal healthy subjects were absence of clinical symptoms and signs suggestive of active PTB and had a normal chest X-ray. No medical history of TB or other infectious diseases, autoimmune diseases, cancer or other diseases that affect host immunity were observed in the control group. $\mathrm{C}$ reactive protein $(\mathrm{CRP})$ was measured for the control group and only negative CRP results were used in the final analysis. The Dean for research affairs of the University Ethics Committee approved the protocol prior to commencing the study.

DNA extraction. Genomic DNA was extracted from $200 \mu 1$ of peripheral blood in EDTA using the DNA extraction kit (Roche Diagnostics, Mannheim, Germany).

Genotyping of VDR Fok1, Taq1 and Bsm1 polymorphisms. Genotypes were detected using a polymerase chain reaction-restriction fragment length polymorphism (PCR-RFLP). The primer sequences, annealing temperature, restriction enzymes and fragments sizes are shown in Table I. PCR was performed in a $25 \mu \mathrm{l}$ final volume containing $25 \mathrm{pmol}$ of each primer, $0.1 \mathrm{mmol} / 1 \mathrm{dNTP}$ (Fermentas, Lithuania), $0.3 \mu \mathrm{g}$ genomic DNA, $1.5 \mathrm{mmol} / 1 \mathrm{MgCl}_{2}, 2.5 \mu 1$ 10X PCR buffer and 1.5 units Taq DNA polymerase (Fermentas), according to the following protocol: Initial denaturation at $94^{\circ} \mathrm{C}$ for $4 \mathrm{~min}$; 30 cycles of denaturation at $94^{\circ} \mathrm{C}$ for $45 \mathrm{sec}$, annealing for $30 \mathrm{sec}$ and extension at $72^{\circ} \mathrm{C}$ for $45 \mathrm{sec}$; and final extension at $72^{\circ} \mathrm{C}$ for $5 \mathrm{~min}$. The PCR products were digested overnight with Fokl, Taql and Bsml restriction endonucleases (Fermentas) and visualized in $2.5 \%$ agarose gel electrophoresis.
The presence and absence of a restriction site were assigned a lowercase and uppercase letter, respectively ( $a$ and $A$ for Apal, $t$ and $T$ for Taql, $f$ and $F$ for Fokl, $b$ and $B$ for Bsml).

Statistical analysis. The statistical analysis of the data was performed using SPSS software for Windows, version 20 (SPSS, Inc., Chicago, IL, USA). The differences between the groups were analyzed by independent sample t-test, $\chi^{2}$ test or Fisher's exact test, as appropriate. The $\chi^{2}$ test was used for deviation of genotype distribution from the Hardy-Weinberg equilibrium. Allele frequencies were calculated by the gene counting method. The odds ratio (OR) and $95 \%$ confidence interval (CI) for each variable were also estimated. The frequency of haplotypes was calculated using PHASE software, version 2.1 (13). Logistic regression analysis was used to assess the independent effect of each risk polymorphism and haplotypes on TB. Bonferroni's post hoc correction was applied to confirm the association of haplotypes with the disease. A two-sided significance level of 0.05 was considered to indicate a statistically significant difference. The computation of LD between single-nucleotide polymorphisms (SNPs) was estimated using the normalized measure of allelic association $D^{\prime}$ and the characterization of these patterns was determined using Haploview software, version 4.2 (http://www.broad.mit. edu/mpg/haploview).

\section{Results}

Patient characteristics. The demographic and clinical characteristics of PTB patients and controls are shown in Table II. There was no statistically significant difference in gender, age and ethnic characteristics in the patients compared to the control subjects. The frequency of smokers was significantly higher in the PTB patients compared to controls (47 vs. 35; $\mathrm{P}=0.0001$ ).

Genotype frequencies. The genotype and allele frequencies of $V D R$ polymorphisms in PTB patients and healthy controls are shown in Table III. All loci conformed to the Hardy-Weinberg equilibrium in the patient and control groups $(\mathrm{P}>0.05)$.

The frequency of the VDR Ff genotype was significantly higher in PTB patients compared to controls and the PTB risk was two times higher in individuals with $F f$ genotype prior and subsequent to adjustment for age, gender, smoking and ethnicity.

However, the frequency of the $f f$ genotype was not different between the two groups prior and subsequent to adjustment for age, gender, smoking and ethnicity. A higher frequency of the $f$ allele was observed in TB patients and the $f$ allele may be a risk factor for PTB predisposition (OR, 1.8; 95\% CR, 1.2-2.8; $\mathrm{P}=0.006$ ). These findings showed that there were no significant difference regarding VDR Bsml and Taql polymorphisms among the PTB patients and control group.

The LD patterns of the three VDR SNPs are shown in Fig. 1. The frequency of seven common haplotypes of the three $V D R$ SNPs $[F o k l(C / T), \operatorname{Taql}(T / C)$ and $B \operatorname{sml}(A / G)]$ are shown in Table IV. The frequency of $f-T-B$ and $f-t-b$ haplotypes was significantly higher in PTB patients compared to controls and haplotype-based association analysis revealed that the $f-T-B$ and $f-t-b$ haplotypes may have the potential to increase PTB susceptibility (OR, 1.3; 95\% CR, 1.1-1.5; P=0.014 and OR, 1.1; 
Table I. Primer sequences, annealing temperature, restriction enzymes and fragment sizes of the vitamin D receptor gene polymorphisms.

\begin{tabular}{|c|c|c|c|c|c|}
\hline $\begin{array}{l}\text { Target } \\
\text { sequence }\end{array}$ & Primer sequence & $\begin{array}{c}\text { Annealing } \\
\text { temperature, }{ }^{\circ} \mathrm{C}\end{array}$ & $\begin{array}{l}\text { PCR } \\
\text { product }\end{array}$ & RFLP fragments & Refs \\
\hline \multirow[t]{2}{*}{ Fokl } & F: 5'-AGCTGGCCCTGGCACTGACTCTGGCT-3' & \multirow[t]{2}{*}{57} & \multirow[t]{2}{*}{267} & $F(\mathrm{C}): 305$ & \\
\hline & R: 5'-ATGGAAACACCTTGCTTCTTCTCCCTC-3' & & & $f(\mathrm{~T}): 115,190$ & 11 \\
\hline \multirow[t]{2}{*}{ Taq1 } & F: 5'-GGGACGATGAGGGATGGACAGAGC-3' & \multirow[t]{2}{*}{61} & \multirow[t]{2}{*}{716} & $T(\mathrm{~T}): 512,204$ & \\
\hline & R: 5'-GGAAAGGGGTTAGGTTGGACAGGA-3' & & & $t(\mathrm{C}): 311,201,204$ & 11 \\
\hline \multirow[t]{2}{*}{ Bsml } & F: 5'-AACTTGCATGAGGAGGAGCATGTC-3' & \multirow[t]{2}{*}{61} & \multirow[t]{2}{*}{813} & $B(\mathrm{~A}): 813$ & \\
\hline & R: 5'-GGAGAGGAGCCTGTGTCCCATTTG-3' & & & $b(\mathrm{G}): 335,478$ & 11 \\
\hline
\end{tabular}

PCR, polymerase chain reaction; RFLP, restriction fragment length polymorphism.

Table II. Demographic characteristics of pulmonary tuberculosis (PTB) patients and controls.

\begin{tabular}{|c|c|c|c|c|}
\hline Variables & $\begin{array}{c}\text { PTB } \\
n=120\end{array}$ & $\begin{array}{c}\text { Controls } \\
n=131\end{array}$ & P-value & $\begin{array}{c}\text { OR } \\
(95 \% \mathrm{CI})\end{array}$ \\
\hline Age, years & $51.5 \pm 19.7$ & $48.1 \pm 12.2$ & 0.1 & \\
\hline Gender (M/F) & $45 / 75$ & $38 / 93$ & 0.09 & \\
\hline Smoking, n (\%) & $47(39)$ & $35(27)$ & 0.0001 & $3.2(1.8-5.8)$ \\
\hline Race, n (\%) & & & 0.1 & \\
\hline Persian & $46(38)$ & $34(26)$ & & \\
\hline Balouch & $70(59)$ & $90(69)$ & & \\
\hline Afghan & $4(3)$ & $7(5)$ & & \\
\hline
\end{tabular}

OR, odds ratio; $\mathrm{CI}$, confidence interval; $\mathrm{M}$, male; F, female.

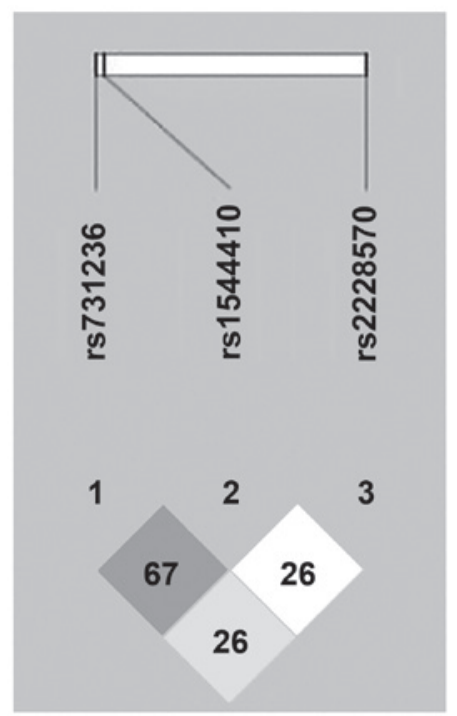

Figure 1. Linkage disequilibrium pattern of three single nucleotide polymorphisms in the vitamin D receptor gene.

95\% CR, 1-1.2; $\mathrm{P}=0.012$ respectively). The association was also statistically significant following post hoc Bonferroni's correction.

\section{Discussion}

TB is a global health problem and its incidence is not the same in different countries, ethnic groups and populations. Much evidence supports an important role for host genetic variations in the predisposition to TB, therefore, the combination effect of genetic and environmental factors may influence the development of TB (14). In addition, there is other evidence that emphasizes the variations in ethnicity for the susceptibility to TB (15). Different candidate genes have been examined in associated studies to evaluate the identity of the TB 'susceptibility factors,' including human leukocyte antigen $(16,17)$, natural-resistance-associated macrophage protein $1(16,17)$, $\operatorname{VDR}(11,16)$, cluster of differentiation 14 (18), interleukins (19) and Toll-like receptors (20).

Several studies have reported a higher frequency of vitamin $\mathrm{D}$ deficiency among TB patients and high doses of vitamin D were extensively used for TB treatment $(11,21)$. In vivo studies showed that vitamin D suppressed intracellular growth of M. tuberculosis (22). Cathelicidin expression, which is the first line of defense in patients, is induced by vitamin $\mathrm{D}$ (23).

The active form of vitamin $\mathrm{D}$ can lead to macrophage activation and subsequently limit the intracellular growth of M. tuberculosis. This vitamin exerts its effect via binding to VDR in the monocytes, therefore the VDR gene polymorphisms are suggested to be involved in genetic susceptibility to TB (24). The association between the VDR polymorphisms and TB susceptibility has been studied in different populations and the results were contradictory $(10,25-27)$.

In the present study, a higher frequency of the VDR Ff genotype of the Fokl polymorphism was observed in the patients compared to the controls. Therefore, this genotype may be considered as a genetic risk factor for the PTB susceptibility. Additionally, the presence of the Fokl mutated allele ( $f$ allele), either in the heterozygous or homozygous state, increased the disease risk.

There were no associations between the VDR Taql and Bsml polymorphisms and PTB. The frequency of the $f-T-B$ and $f-t-b$ haplotypes of the $\operatorname{VDR} \operatorname{Fokl}(C / T), \operatorname{Taql}(T / C)$ and $B \operatorname{sml}(A / G)$ polymorphisms were significantly higher in PTB patients.

An association between 25-hydroxycholecalciferol deficiency and occurrence of TB among the Gujarati Asian 
Table III. Genotype and allele frequencies of vitamin D receptor (VDR) gene polymorphisms in pulmonary tuberculosis (PTB) patients and healthy controls.

\begin{tabular}{|c|c|c|c|c|c|c|}
\hline$V D R$ polymorphisms & PTB, $n=120(\%)$ & Controls, $\mathrm{n}=131(\%)$ & P-value & OR $(95 \% \mathrm{CI})$ & P-value & $\mathrm{OR}^{\mathrm{a}}(95 \% \mathrm{CI})$ \\
\hline \multicolumn{7}{|l|}{ Fokl } \\
\hline$F F$ & $65(54)$ & $93(71)$ & & 1 & & \\
\hline$F f$ & $44(37)$ & $31(24)$ & 0.013 & $2.0(1.2-3.6)$ & 0.015 & $2.0(1.2-3.6)$ \\
\hline$f f$ & $11(9)$ & $7(5)$ & 0.1 & $1.5(0.9-2.5)$ & 0.08 & $1.6(1-2.6)$ \\
\hline$F f+f f$ & $55(46)$ & $38(29)$ & 0.006 & $2.1(1.2-3.5)$ & 0.006 & $2.1(1.2-3.6)$ \\
\hline$F$ & $174(73)$ & $217(83)$ & & 1 & & - \\
\hline$f$ & $66(27)$ & $45(17)$ & 0.006 & $1.8(1.2-2.8)$ & & \\
\hline \multicolumn{7}{|l|}{ Taq1 } \\
\hline$T T$ & $52(43)$ & $67(51)$ & & 1 & & \\
\hline$T t$ & $54(45)$ & $50(38)$ & 0.2 & $1.4(0.8-2.4)$ & 0.17 & $1.5(0.9-2.5)$ \\
\hline$t t$ & $14(12)$ & $14(11)$ & 0.6 & $1.1(0.8-1.7)$ & 0.5 & $1.2(0.8-1.8)$ \\
\hline$T t+t t$ & $68(57)$ & $64(49)$ & 0.2 & $1.4(0.8-2.3)$ & 0.2 & $1.4(0.9-2.3)$ \\
\hline$T$ & $158(66)$ & $184(70)$ & & 1 & & - \\
\hline$t$ & $82(34)$ & $78(30)$ & 0.3 & $1.2(0.8-1.8)$ & & - \\
\hline \multicolumn{7}{|l|}{ Bsml } \\
\hline$B B$ & $31(26)$ & $39(30)$ & & 1 & & \\
\hline$B b$ & $66(55)$ & $70(53)$ & 0.6 & $1.2(0.7-2.1)$ & 0.7 & $1.1(0.6-2)$ \\
\hline$b b$ & $23(19)$ & $22(17)$ & 0.5 & $1.2(0.8-1.7)$ & 0.4 & $1.2(0.8-1.7)$ \\
\hline$B b+b b$ & $89(74)$ & $92(70)$ & 0.5 & $1.2(0.7-2.1)$ & 0.6 & $1.2(0.7-2.1)$ \\
\hline$B$ & $128(53)$ & $148(57)$ & & 1 & & \\
\hline$b$ & $112(47)$ & $114(43)$ & 0.5 & $1.1(0.8-1.6)$ & & \\
\hline
\end{tabular}

${ }^{\mathrm{a} O R}$, adjusted OR for age, gender, smoking and ethnicity. OR, odds ratio; CI, confidence interval.

Table IV. Haplotypes frequency of vitamin D receptor gene polymorphisms in pulmonary tuberculosis (PTB) patients and controls.

\begin{tabular}{lcccccc}
\hline Fokl & Taql & Bsml & PTB $\%$ & Control $\%$ & P-value & OR (95\% CI) \\
\hline$F$ & $T$ & $B$ & 39.2 & 47.7 & & 1 \\
$F$ & $T$ & $b$ & 15.8 & 14.9 & 0.3 & $1.3(0.8-2.2)$ \\
$F$ & $t$ & $B$ & 4.2 & 4.2 & 0.7 & $1.1(0.7-1.7)$ \\
$F$ & $t$ & $b$ & 13.3 & 16 & 0.96 & $1.0(0.8-1.2)$ \\
$f$ & $T$ & $B$ & 9.6 & 4.6 & 0.014 & $1.3(1.1-1.5)$ \\
$f$ & $T$ & $b$ & 1.2 & 3.1 & 0.3 & $0.9(0.7-1.1)$ \\
$f$ & $t$ & $b$ & 16.2 & 9.5 & 0.012 & $1.1(1-1.2)$ \\
\hline
\end{tabular}

OR, odds ratio; CI, confidence interval.

population in west London has been reported previously. In addition, a significant interaction between the vitamin D status and Fokl and Taql polymorphisms and TB was observed (11).

There was an association between ff genotype of Fokl but not Taql polymorphism and susceptibility to PTB in Chinese Han population (25).

Although there has not been any reported association between the VDR Taql and Fokl polymorphisms and PTB susceptibility in Peru, an association between the VDR gene polymorphism and response to treatment of PTB has been observed (26). In a case control study in West Africa, no association between TB and the VDR Fokl, Bsml, Apal and Taql variants was reported; however, the $F A$ haplotype of the Fokl and Apal polymorphisms was correlated with TB susceptibility (10). Although the study by Lombard et al (28) did not report any correlation between the VDR Fokl, Bsml, Apal and Taql polymorphisms and TB, the $F-b-A-T$ haplotype was observed as a protective factor for TB in South Africa.

Similar to the results of the present study, the association between the Fokl polymorphism, but not the Taql polymorphism, of the VDR gene with PTB has been observed in the Chinese Tibetan population (29). 
The results of Alagarasu et al (30) indicated that the $b$-A-T haplotype of the $3^{\prime} \mathrm{UTR} V D R$ gene played a protective role against human immunodeficiency virus (HIV) infection, whereas the $B-A-t$ haplotype may be associated with susceptibility to the development of TB in HIV-1-infected patients.

In contrast to the results of the present study, Banoei et al (31) revealed that the $t t$ and $b b$ genotypes of the VDR Taq1 and Bsml polymorphisms are associated with the predisposition to PTB in an Iranian population. In another study, Merza et al (32) also confirmed the association of the VDR Bsml $(B b+b b)$ polymorphism and PTB in a local Iranian population.

In a meta-analysis that was performed on 23 studies in 2010, an association between the Fokl ff genotype and TB has been observed among the Asian population (OR, 2.0; 95\% CR, 1.3-3.2). Additionally a significant inverse association was observed for the $B s m l b b$ genotype (OR, 0.5; 95\% CR, 0.4-0.8). There were no associations between these polymorphisms and TB among the African or South American populations (27). The association between the VDR Fokl polymorphism and extra-PTB and spinal TB has been reported in American and Chinese Han populations, respectively $(33,34)$.

In another study, no correlation between the Taq1, Bsml and Fokl polymorphisms were found for host susceptibility to human TB in the Korean population (35).

Consistent with the findings of the present study, a higher frequency of the Fokl $F f$ and $f f$ genotypes in TB patients has been reported in the Chinese Kazak population. There were no significant differences of the Taql-Tt and $t t$ genotype frequencies between TB patients and healthy controls (16).

Although the reason for this discrepancy remains unclear, these different results in the association studies are common and may be due to the different genetic background of various populations, different selection criteria adopted for patients and controls in particular clinical presentation and environmental risk factors.

There were certain limitations in the present study, such as a small sample size and different ethnic groups (Fars and Balouch) existing in southeast Iran. Therefore, further investigations using a larger sample size and different ethnic groups are necessary to confirm the present results.

In conclusion, the results showed that the VDR Ff genotype and $f$ allele of the Fok1 polymorphism was associated with PTB susceptibility. There were no associations between the VDR Taql and Bsml polymorphisms and PTB. In addition, the frequency of the $f-T-B$ and $f-t-b$ haplotypes was significantly higher in the PTB patients.

\section{Acknowledgements}

The present study was extracted from the Master of Science thesis (Comparison of VDR gene polymorphisms frequency in PTB patients and healthy controls. Zahedan University of Medical Sciences. Registered no. 1312) at Zahedan University of Medical Sciences. The authors would like to thank the Deputy of Research Affairs at the University for funding this project.

\section{References}

1. Global tuberculosis control: WHO report 2010. World Health Organization, Geneva, Switzerland, 2010 (WHO/HTM/TB/2010.7).
2. Centers for Disease Control and Prevention: Reported tuberculosis in Sistan and Baluchestan, Iran. CDC, Atlanta, GA, 2009.

3. Flynn JL and Chan J: Immunology of tuberculosis. Annu Rev Immunol 19: 93-129, 2001.

4. Casanova JL and Abel L: Genetic dissection of immunity to mycobacteria: the human model. Annu Rev Immunol 20: 581-620, 2002.

5. Comstock GW: Tuberculosis in twins: a re-analysis of the Prophit survey. Am Rev Respir Dis 117: 621-624, 1978.

6. Blackwell JM: Genetics and genomics in infectious disease susceptibility. Trends Mol Med 7: 521-526, 2001.

7. Bellamy R, Ruwende C, Corrah T, et al: Tuberculosis and chronic hepatitis B virus infection in Africans and variation in the vitamin D receptor gene. J Infect Dis 179: 721-724, 1999.

8. Bar-Shavit Z, Noff D, Edelstein S, Meyer M, Shibolet S and Goldman R: 1,25-dihydroxyvitamin D3 and the regulation of macrophage function. Calcif Tissue Int 33: 673-676, 1981.

9. Haussler MR, Haussler CA, Bartik L, et al: Vitamin D receptor: molecular signaling and actions of nutritional ligands in disease prevention. Nutr Rev 66 (Suppl 2): S98-S112, 2008.

10. Bornman L, Campbell SJ, Fielding K, et al: Vitamin D receptor polymorphisms and susceptibility to tuberculosis in West Africa: a case-control and family study. J Infect Dis 190: 1631-1641, 2004.

11. Wilkinson RJ,Llewelyn M, Toossi Z, et al: Influence of vitamin D deficiency and vitamin $\mathrm{D}$ receptor polymorphisms on tuberculosis among Gujarati Asians in west London: a case-control study. Lancet 355: 618-621, 2000.

12. Uitterlinden AG, Fang Y, Van Meurs JB, Pols HA and Van Leeuwen JP: Genetics and biology of vitamin D receptor polymorphisms. Gene 338: 143-156, 2004.

13. Scheet P and Stephens M: A fast and flexible statistical model for large-scale population genotype data: applications to inferring missing genotypes and haplotypic phase. Am J Hum Genet 78: 629-644, 2006.

14. Mathema B, Kurepina NE, Bifani PJ and Kreiswirth BN: Molecular epidemiology of tuberculosis: current insights. Clin Microbiol Rev 19: 658-685, 2006.

15. Hoal EG: Human genetic susceptibility to tuberculosis and other mycobacterial diseases. IUBMB Life 53: 225-229, 2002.

16. Wu F, Zhang W, Zhang L, et al: NRAMP1, VDR, HLA-DRB1, and HLA-DQB1 gene polymorphisms in susceptibility to tuberculosis among the Chinese Kazakh population: a case-control study. Biomed Res Int 2013: 484535, 2013.

17. Bellamy R, Ruwende C, Corrah T, McAdam KP, Whittle HC and Hill AV: Variations in the NRAMP1 gene and susceptibility to tuberculosis in West Africans. N Engl J Med 338: 640-644, 1998.

18. Alavi-Naini R, Salimi S, Sharifi-Mood B, Davoodikia AA, Moody B and Naghavi A: Association between the CD14 gene C-159T polymorphism and serum soluble CD14 with pulmonary tuberculosis. Int J Tuberc Lung Dis 16: 1383-1387, 2012.

19. Trajkov D, Trajchevska M, Arsov T, et al: Association of 22 cytokine gene polymorphisms with tuberculosis in Macedonians. Indian J Tuberc 56: 117-131, 2009.

20. Jahantigh D, Salimi S, Alavi-Naini R, Emamdadi A, Owaysee Osquee $\mathrm{H}$ and Farajian Mashhadi F: Association between TLR4 and TLR9 gene polymorphisms with development of pulmonary tuberculosis in Zahedan, southeastern Iran. ScientificWorldJournal 2013: 534053, 2013.

21. Nursyam EW, Amin Z and Rumende CM: The effect of vitamin D as supplementary treatment in patients with moderately advanced pulmonary tuberculous lesion. Acta Med Indones 38: 3-5, 2006.

22. Rockett KA, Brookes R, Udalova I, Vidal V, Hill AV and Kwiatkowski D: 1,25-Dihydroxyvitamin D3 induces nitric oxide synthase and suppresses growth of Mycobacterium tuberculosis in a human macrophage-like cell line. Infect Immun 66: 5314-5321, 1998.

23. Gombart AF: The vitamin D-antimicrobial peptide pathway and its role in protection against infection. Future Microbiol 4: 1151-1165, 2009.

24. Herr C, Greulich T, Koczulla RA, et al: The role of vitamin D in pulmonary disease: COPD, asthma, infection, and cancer. Respir Res 12: 31, 2011.

25. Liu W, Cao WC, Zhang CY, et al: VDR and NRAMP1 gene polymorphisms in susceptibility to pulmonary tuberculosis among the Chinese Han population: a case-control study. Int J Tuberc Lung Dis 8: 428-434, 2004.

26. Roth DE, Soto G, Arenas F, et al: Association between vitamin D receptor gene polymorphisms and response to treatment of pulmonary tuberculosis. J Infect Dis 190: 920-927, 2004. 
27. Gao L, Tao Y, Zhang L and Jin Q: Vitamin D receptor genetic polymorphisms and tuberculosis: updated systematic review and meta-analysis. Int J Tuberc Lung Dis 14: 15-23, 2010.

28. Lombard Z, Dalton DL, Venter PA, Williams RC and Bornman L: Association of HLA-DR, -DQ, and vitamin D receptor alleles and haplotypes with tuberculosis in the Venda of South Africa. Hum Immunol 67: 643-654, 2006.

29. Chen XR, Feng YL, Ma Y, et al: Study on the association of two polymorphisms of the vitamin D receptor (VDR) gene with the susceptibility to pulmonary tuberculosis (PTB) in Chinese Tibetans. Sichuan Da Xue Xue Bao Yi Xue Ban 37: 847-851, 2006 (In Chinese).

30. Alagarasu K, Selvaraj P, Swaminathan S, Narendran G and Narayanan PR: 5' regulatory and 3' untranslated region polymorphisms of vitamin D receptor gene in south Indian HIV and HIV-TB patients. J Clin Immunol 29: 196-204, 2009.

31. Banoei MM, Mirsaeidi MS, Houshmand M, et al: Vitamin D receptor homozygote mutant tt and bb are associated with susceptibility to pulmonary tuberculosis in the Iranian population. Int $\mathrm{J}$ Infect Dis 14: e84-e85, 2010.
32. Merza M, Farnia P, Anoosheh S, et al: The NRAMPI, VDR and TNF-alpha gene polymorphisms in Iranian tuberculosis patients: the study on host susceptibility. Braz J Infect Dis 13: 252-256, 2009.

33. Motsinger-Reif AA, Antas PR, Oki NO, Levy S, Holland SM and Sterling TR: Polymorphisms in IL-1beta, vitamin D receptor Fok1, and Toll-like receptor 2 are associated with extrapulmonary tuberculosis. BMC Med Genet 11: 37, 2010.

34. Zhang HQ, Deng A, Guo CF, et al: Association between FokI polymorphism in vitamin $\mathrm{D}$ receptor gene and susceptibility to spinal tuberculosis in Chinese Han population. Arch Med Res 41: 46-49, 2010.

35. Kang TJ, Jin SH, Yeum CE, et al: Vitamin D receptor gene TaqI, BsmI and FokI polymorphisms in Korean patients with tuberculosis. Immune Netw 11: 253-257, 2011. 